\title{
光ファイバを用いた $\mathrm{Al}$ 一引き抜き GFRP 接着接合部のはく離検出 ${ }^{\dagger}$
}

$$
\begin{array}{llll}
\text { 逢 坂 勝彦* 福 田 武 } \text { 人 }^{*} \\
\text { 坂 本 勝 彦** }
\end{array}
$$

\section{Detection of the Debonding in Al-Pultruded GFRP Adhesively Bonded Joints with Optical Fibers}

\author{
by \\ Katsuhiko OsaKa ${ }^{*}$, Takehito FuKudA ${ }^{*}$, Katsuhiko SAKAmoto ** \\ and Mitsuo KoBayashi ${ }^{* * *}$
}

In the present study, methods in which the debonding is detected in the adhesively bonded joint constructed with aluminum and pultruded GFRP (PULGFRP) plates using an optical fiber have been investigated. The proposed detecting methods for the debonding in the bonded joints utilize the breakage of the embedded optical fiber caused by the damage such as cracks. In the present study, two detecting methods for the debonding in which the situations of the embedded optical fiber in the bonded joint were different were adopted, and their ability of detecting the debonding were examined. Further, the effects of embedding the optical fibers in the bonded joints on the strength of the joints were investigated, and the ability of the detection of the debonding in the joints whose adhesives were in undercure was also studied. From these results, the applicability of these detecting methods to the health-monitoring system were investigated. As the conclusions it was obtained that one of the two methods could be applied to the health-monitoring system as the detecting method for the debonding in the Al-PULGFRP adhesively bonded joints.

Key words : Pultruded GFRP, Optical fiber, Adhesively bonded joint, Health-monitoring, Adhesive

\section{1 緒言}

引き抜き FRP を使って構造物を構築する場合には，接 合法が不可欠であり重要となるが, 引き抜き FRP が基本 的に一方向強化材であることから, 穿孔部を介して荷重 を伝達する機械的接合法は好ましくなく, 接着接合法が 適していると考えられる. しかし，接着接合法は特に構 造物の施工現場での接合作業を考えたとき, 機械的接合 法に対して信頼性が低く，現実にはあまり採用されてい ないのが現状である。 そこで, 工場で引き抜き FRP の両 端に金属製の接合部品を接着接合し，その接合部品同士 を施工現場で機械的に接合して構造物を構築する, 2 種 類の接合法を組み合わせた方法が，それぞれの欠点を補 った引き抜き FRPに適した接合法と考えられる。しか し，引き抜き FRP の接合に関しては，ボルトによる機械 的結合法に関する研究は行われているものの,, 2) この組 み合わせ接合法に関する研究は少ない. A. Pickettらが, 両端に金属製のスリーブを接着した引き抜き GFRP パイ プを, 金属製の結合部品を介して結合し, スペース・フ レームを構筑することを目的として行った研究が発表さ

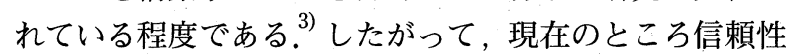
を有する引き抜き FRP に適した接合法が確立されていな いのが現状である.
接合部の信頼性を確保する方法としては，まず，接合 部の強度特性を明らかにしておく必要があるが, 他の方 法として, 最近注目を集めている損傷検出センサを構造 部材に埋め込み，センサからの信号を常に監視して構造 物の健全性を確保するへルスモニタリングという手法が 考えられる．特にFRPに対するへルスモニタリングでは， 光ファイバがセンサとして適していると考えられている. 光ファイバセンサによる損傷検出法としては, 構造部材 内部のひずみを測定してひずみ変化より内部の損傷状態 を検出しようとする方法と, 埋め込まれた光ファイバが 構造部材のクラックなどの内部損傷により破断すること で，損傷の発生を検出する方法が考えられる，ひずみ測 定に関する研究では，高性能な光ファイバのひずみ測定 システムの開発が現在のところ主である. ${ }^{5) ~ 10)}$ 一方, 光 ファイバの破断による損傷検出については, 光ファイバの 埋め込み方法, 光ファイバの表面処理などによる損傷検 出能力の向上に関して検討が行われている..$^{11) \sim 13)}$ また, 疲労損傷 , 衝撃損傷の検出についても検討されている. 15) ヘルスモニタリングの構造物への適用を考えたとき， 以上の光ファイバを使用した損傷の検出手法に加えて， センサからの信号を構造物の健全性を示す指標に変換し, 表示するシステムが必要である。ひずみ測定法ではひず

$\dagger \quad$ 原稿受理 平成 10 年 8 月 6 日 Received Aug. 6, 1998

* 正会員 大阪市立大学工学部知的材料工学科 = 558-8585 大阪市住吉区杉本, Dept. of Intelligent Materials Eng., Osaka City Univ., Sumiyoshi-ku, Osaka, 558-8585

** (㮫)日本触媒樹脂研究所 $=564-0034$ 吹田市西御旅町, Nippon Shokubai Co. Ltd., NishiOtabi-cho, Suita, 564-0034

*** 日本ポリエステル(株)三田工場％669-1339三田市テクノパーク, Nippon Polyester Co., Ltd., Technopark, Sanda, 669-1339 
み測定技術の確立が行われている段階であり，実際に大 型構造物に適用できる信頼性のあるシステムについては ほとんど検討されていない。一方, 光ファイバの破断に よる損傷の検出方法については，B. Hoffer が，CFRPを 機体に使用したエアバスを想定して，エアバス全体に光 ファイバを張り巡らし，コックピットでその機体全体の損 傷状態をモニタできるシステムについて提案している。 ${ }^{16)} \mathrm{B}$. Hofferの研究が示すように, エアバスのような巨大な構 造物についても，光ファイバの破断を損傷の検出に利用 する方法であれば，コックピットに全機体の健全性を表 示するへルスモニタリング : システムの構築が可能であ ることがわかる. 以上のことより, 引き抜き FRP 構造物 への光ファイバを使ったへルスモニタリングの適用にお いては，損傷の検出手法として光ファイバの破断による 方法が実現性が高いと考えられる。一方, 接合部の光つ アイバによる損傷の検出については，ボルト接合部の変 位を光ファイバにより測定し，損傷状態を検出しようと する研究が行われている. ${ }^{17)}$ しかし, 光ファイバの破断を 利用した損傷検出については, 先に述べた B. Hofferの 研究で, 機体のスキンとフレームの接着接合部などに光 ファイバを埋め込み，そのはく離なでの損傷状態を光フ アイバにより検出することが可能であることを示してい る程度であり, 詳細な检討が行われているわけではない。

そこで, 本研究では金属製の接合部品と引き抜き FRP の接着接合部のへルスモニタリングを目的として $\mathrm{Al}$ 一引 き抜き GFRP 接着継手を取り上げ，その接着接合部につ いて接合部に埋め込まれた光ファイバの破断を利用した， はく離検出法について検討した. 実験では光ファイバの 埋め込み方法が異なる 2 種類のはく離検出方法を取り上 げ，そのはく離検出能力について調べた。 また，接着剤 が硬化不良の状態に打けるはく離検出能力打よび光ファ イバを埋め込んだことによる接着継手強度への影響につ いても調べ, 2 種類のはく離検出方法について, そのへ ルスモニタリングへの適応性を検討した.

\section{$2 \cdot 1$ 実験方法}

\section{2 光ファイバによるはく離検出}

$2 \cdot 1 \cdot 1$ 被着材 実験にはアルミニウム合金平板と 引き抜き GFRP 平板をエポキシ接着剤で接着した, $\mathrm{Al}-$ 引き抜き GFRP 接着継手試験片を使用した。 Fig. 1 に接 着継手の被着材として使用した引き抜き GFRP (PULGFRP) の素材構成を示す. 図に示すように, GFRP 材 は 3 層のサンドイッチ構造をしている.引き抜き方向に ガラスロービングにより強化された層 (Roving layer) が ほぼ全体を占めて扔り，その上下にコンティニュアスマ ットにより強化された層 (Mat layer) がある.このマッ 卜層は, 一方向強化ガラスロービング層の繊維と直交す る方向の補強材となっている. GFRP 板全体としての板 厚は $4 \mathrm{~mm}$ ，コンティニュアスマット層 1 層あたりの厚さ は約 $0.3 \mathrm{~mm}$ である。この引き抜き GFRP 板の機械的性 質を Table Iに示す。な打, アルミニウム合金としては ジュラルミン A2017を使用した。

$2 \cdot 1 \cdot 2$ 光ファイバ 接着継手試験片のはく離検出
には石英光ファイバを使用した。 その構成を Fig. 2 に示 す. 図に示すように, 光ファイバにはレーザ光を伝える コア部, その外側にクラッド部があり,これが光ファイ バのレーザ光を伝達する本来の機能を果たす部分である. これらは，石英ガラス製である。 そして，保護のために その外側をポリウレタン製の被覆材が覆っている.コア 部直径が 8 ミクロン, クラッド部直径が 125 ミクロン, ポリウレタン部直径が 250 ミクロンである.

$2 \cdot 1 \cdot 3$ はく離検出法および接着継手試験片 本研 究で接着部のはく離検出試験に用いた接着継手試験片の 形状と寸法を Fig. 3 に示す。この試験片の接着部にはく 離検出用の光ファイバを埋め込み実験を行うが, 先に述 べたように, 本研究においては光ファイバによる接着部 のはく離㭘出を, 光ファイバの切断により検出する方法 を採用している。したがって，光ファイバの接着部への 埋め込み方法がはく離検出において重要となる。 そこで,

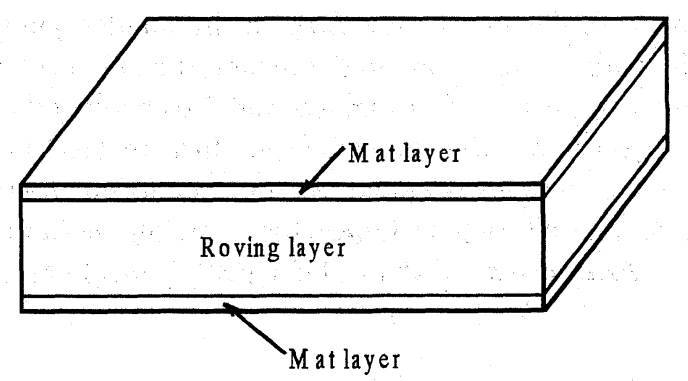

Fig. 1. Structure of PULGFRP adherends.

Table I. Mechanical properties of PULGFRP.

\begin{tabular}{|c|c|c|c|c|}
\hline $\begin{array}{c}\text { Tensile } \\
\text { strength } \\
(\mathrm{MPa})\end{array}$ & $\begin{array}{c}\text { Young's } \\
\text { modulus } \\
(\mathrm{GPa})\end{array}$ & $\begin{array}{c}\text { Bending } \\
\text { strength } \\
(\mathrm{MPa})\end{array}$ & $\begin{array}{c}\text { Bending } \\
\text { modulus } \\
(\mathrm{GPa})\end{array}$ & $\begin{array}{c}\text { Glass } \\
\text { content } \\
(\text { wt\% } \%\end{array}$ \\
\hline 637 & 33.0 & 657 & 21.2 & 64 \\
\hline
\end{tabular}

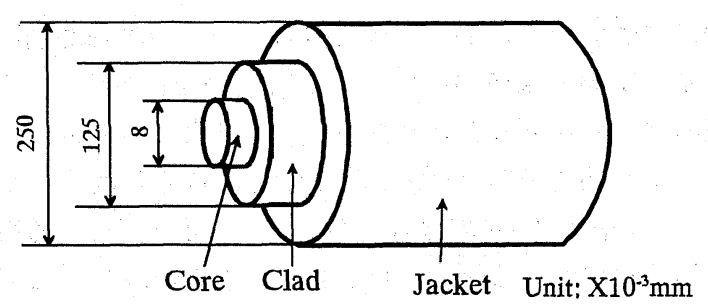

Fig. 2. Structure of optical fibers.

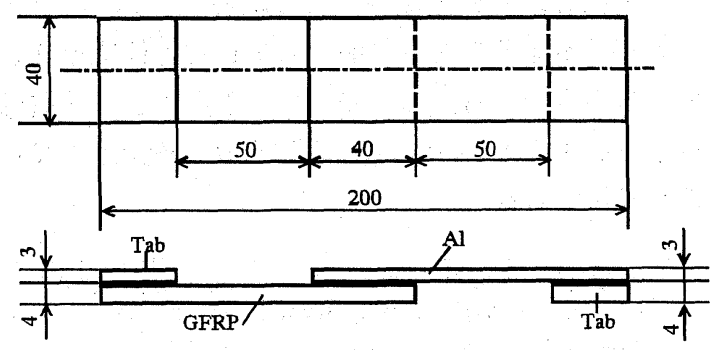

Fig. 3. Al-PULGFRP adhesively bonded joint specimen for monitoring experiments. 
本研究では 2 種類の光ファイバの埋め込み方法を考案し, それぞれの埋め込み方法を採用したはく離検出法につい て検討した：埋め込み方法としてまず考えられるのは， 接着層内に光ファイバを埋め込む方法である。そこで， この埋め込み方法を採用したはく離検出法をまず取り上 げ，Aタイプと呼ぶことにする．実際の試験片への埋め 込み方法を Fig. 4 に示す。困に示すように，接着部のは く離ではなく試験片の破断後の被着材の分離により光フ ァイバが破断することを防ぐため, 光ファイバをU 字形 にして埋め込んでいる．また，光ファイバと接着凨の接 着性をよくするため, 接着部の端の部分 (図中 A 部分) に当たる光ファイバの被覆材を除去して埋め込んでいる. この試験片を以下, A タイプ試験片と呼ぶことにする。 また, 本来は $\mathrm{Al}$ 一引き抜き GFRP 接着継手の接着部の はく離破壊モードに対応した，光ファイバの埋め込み方 法を採用することが望ましいと考えられることから，接 着継手のはく離破壊モードを考虑した光ファイバの埋め 込み方法を採用したはく離検出法を次に取り上げて検討 した， $\mathrm{Al}$ 一引き抜き GFRP接着継手においては，著者ら が先に行った研究から, そのはく離破壊が GFRPの接着 部における表面層の引きはがしによって起こることがわ かっている. ${ }^{18)}$ そこで, Fig. 5 に示すように, 接着部の引 き抜き GFRP に光ファイバ埋め込み用の溝をつくり，溝 部分に光ファイバを埋め込む方法を採用し，この埋め込 み方法を採用したはく離検出法を $\mathrm{G}$ タイプと呼ぶことに する. Fig. 6 に, 光ファイバ埋め込み用の溝の詳細図を 示す. 図中の L は接着部の長さを示している. 光ファイ バは接着部への埋め込み部分全体の被覆材を除去して埋 め込んでいる。したがって，接着後には光ファイバは $0.3 \mathrm{~mm}$ の深さの溝の中に完全に埋め込まれた状態になっ

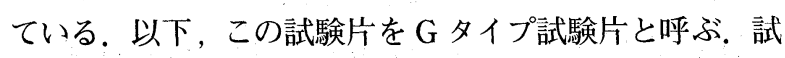
験片の接着においては, エポキシ・ポリアミド系の接着 剤を使用し，接着後 $60^{\circ} \mathrm{C}$ 一定の恒温槽内で 2 日間保持 した.

なお，本研究では接着剤の硬化不良状態における光フ アイバによる接着部のはく離検出能力についても検討す るため, 硬化不良状態の接着継手試験片を製作している が，その点については次に述べる.

$\mathbf{2} \cdot \mathbf{1} \cdot \mathbf{4}$ 試験方法 Fig. 7 に本実験に使用した測定 システムの概略困を示す. 光ファイバによる接着部のは く離検出能力を検証するため, $\mathrm{AE}$ 測定による接着部の 損傷検出も同時に行った. 実験に使用した $\mathrm{AE}$ 測定装置 は 9502U-PLOT (森)エヌネフ回路設計ブロック製); $\mathrm{AE}$ センサには共振周波数 $140 \mathrm{kHz}$ の共振型のものを使用し た. 光ファイバによるはく離検出システムはレーザ光発 生部が温度コントロール治具付きレーザダイオードとレ 一ザドライバより構成され，レーザ光検出部はフォトダ イオードおよびアンプよりなっている. 実験において， $\mathrm{AE}$ 測定装置により検出されたイベントカウントは GP-IB により, また, フォトダイオードにより検出されたレー ザ光の信号は負荷試験機からの荷重信号と同時に A/D 変換され，パーソナルコンピュータに取り达まれる。負
荷試験機には, インストロン型の試験機を使用し，引張 速度 $0.1 \mathrm{~mm} / \mathrm{min}$ で実験を行った。

一般に，接着接合においては，接着剤の硬化不良によ り接着部の強度が設計強度に比べて大きく低下し，低い 荷重で破壊することが起こり得る，接着部において接着 剤が硬化不良を起こした場合，完全硬化した場合のよう に光ファイバと接着剤の接着が完全ではないため, 接着
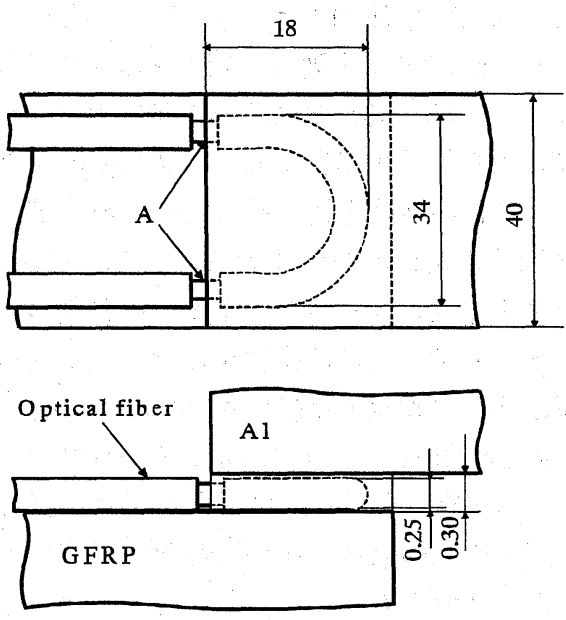

Fig. 4. Situation of the embedded optical fiber at the bonded area of A type specimens.
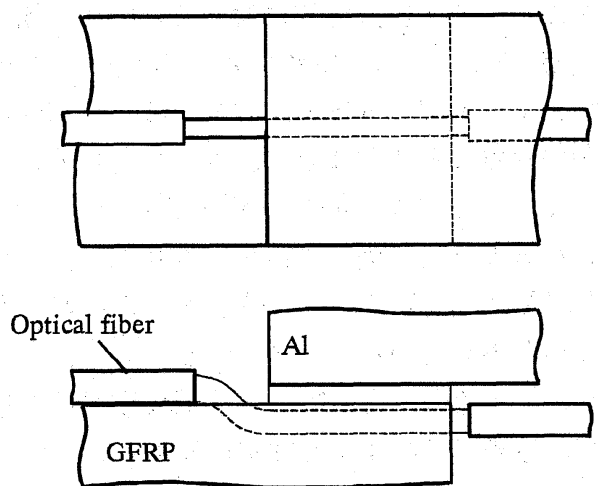

Fig. 5. Situation of the embedded optical fiber at the bonded area of $G$ type specimens.

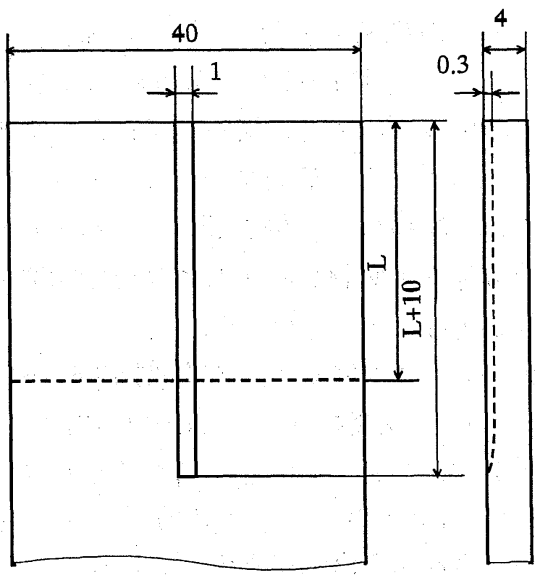

Fig. 6. Dimensions of the groove for embedding optical fiber in $\mathrm{G}$ type specimens. 
部の光ファイバによるはく離検出能力が低下する可能性 が考えられる，そこで，完全硬化状態における場合と同 様に, 2 種類の $\mathrm{Al}$ 一引き抜き GFRP 接着継手について接 着剤が硬化不良状態の試験片を用意し，引張荷重下にお ける光ファイバによる接着部のはく離検出実験を行った. 実験で使用した接着剤の硬化状態を把握するため，まず， 硬化過程における接着剤の誘電率の測定を行った。その 測定には誘電率測定装置 (Micromet instruments 社製 Eumetric 100A）を使用した。内部の寸法が $20 \mathrm{~mm} \times$ $40 \mathrm{~mm} \times 0.5 \mathrm{~mm}$ の型を作製し，測定するべき接着郕をそ の型に充填した後, 接着剤に誘電率測定センサを埋め込 み恒温槽に入れ, 硬化過程において誘電率の測定を行っ た.なお，硬化の進展を遅らせるため，恒温槽の温度は 完全硬化接着の場合の $60^{\circ} \mathrm{C} て ゙ は な く ， 45^{\circ} \mathrm{C}$ に設定した。 測定した誘電率より得られたエポキシ接着剤のイオン粘 度を Fig. 8 に示す。この測定結果に基づき本実験におい ては，硬化不良接着継手試験片を製作する場合の恒温槽 における硬化時間を 240 分に設定した (困中 A 点)。し たがって，本実験における硬化不良接着継手試験片の接 着剂は，完全硬化の場合に比べて約 $80 \%$ 程度のイオン粘 度を示す硬化状態である。

\section{$2 \cdot 2$ 実験結果}

\section{$2 \cdot 2 \cdot 1$ A タイプ試験片(接着剤が完全硬化状態)}

Fig. 9 に 示す．困に扣いて，負荷時間に対する試験片に加えられ た荷重, $\mathrm{AE}$ カウントおよび光ファイバからのレーザ光出 力を下図および上図に分けて示している．横軸は負荷時 間，下図の縦軸に荷重および $\mathrm{AE}$ カゥントを示し，上网 の縦軸に光ファイバからのレーザ光出力を示している。 図からわかるように，破壊の直前（図中 $\mathrm{A}$ 点）から $\mathrm{AE}$ カウントが急増しており, この時点から接着継手の接着 部に損傷が発生していることがわかる。一方，光ファイ バからのレーザ光出力は，接着継手試験片がはく離破壊 し, 荷重が急激に減少すると同時に減少し，この時点で 光ファイバが切断したことがわかる．この結果より，光 ファイバでは $\mathrm{AE}$ 測定により感知できる損傷を検出する ことはできないものの，接着部のはく離は検出できるこ とがわかった．Fig. 10 に接着継手試験片の接着部のは く離破壊モードの模式困を示す。罒に示すように，接着 継手は光ファイバを埋め込んだ接着層および引き抜き GFRP の接着部表面のマット層を引きはがして破壊して いる。したがって，この破壊モードより光ファイバによ る接着部のはく離検出は, 接着層に埋め込まれた光ファ イバが接着端部の被覆材を除去した部分で切断すること により可能であることがわかった.

2・2・2 G タイプ試験片（接着剤が完全硬化状態） Fig. 11 に タイプ試験片のはく離検出実験結果の一例 を示す．罒からわかるように, $\mathrm{G}$ タイプも $\mathrm{A}$ タイプと同 様に $\mathrm{AE}$ カウントの結果より破壊の直前（図中 $\mathrm{A}$ 点）か ら接着継手の接着部に損傷が発生していることがわかる。 また，光ファイバからのレーザ光出力の結果より，A タ イプと同様，接着継手試験片のはく離破壊時に光ファイ
バが切断したことがわかる。これらの結果から，G タイ プにおいても $\mathrm{A}$ タイプと同様, 光ファイバによって, $\mathrm{AE}$ 測定により感知できる損傷を検出することはできないも

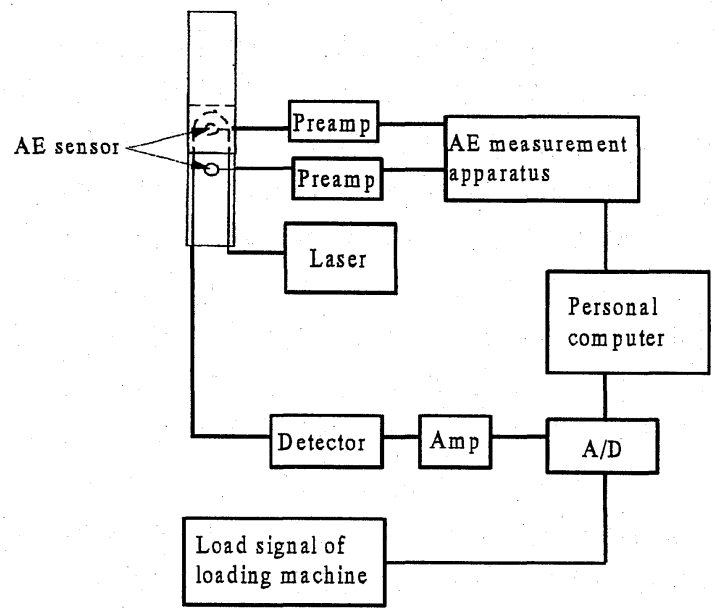

Fig. 7. Measurement system.

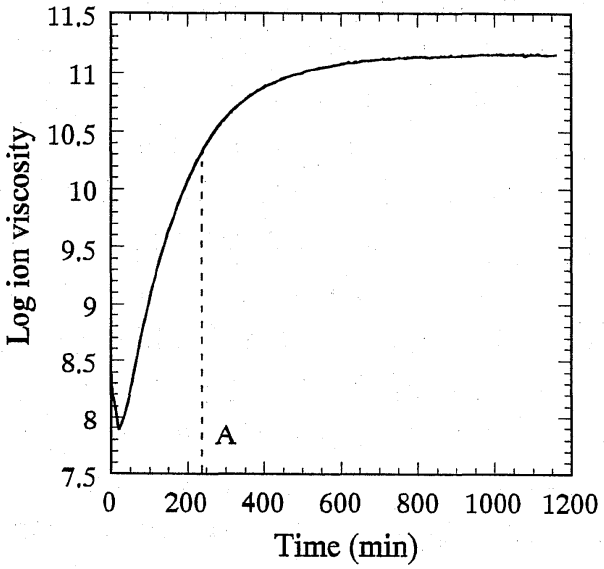

Fig. 8. Ion viscosity of adhesives used for bonding of joint specimens.
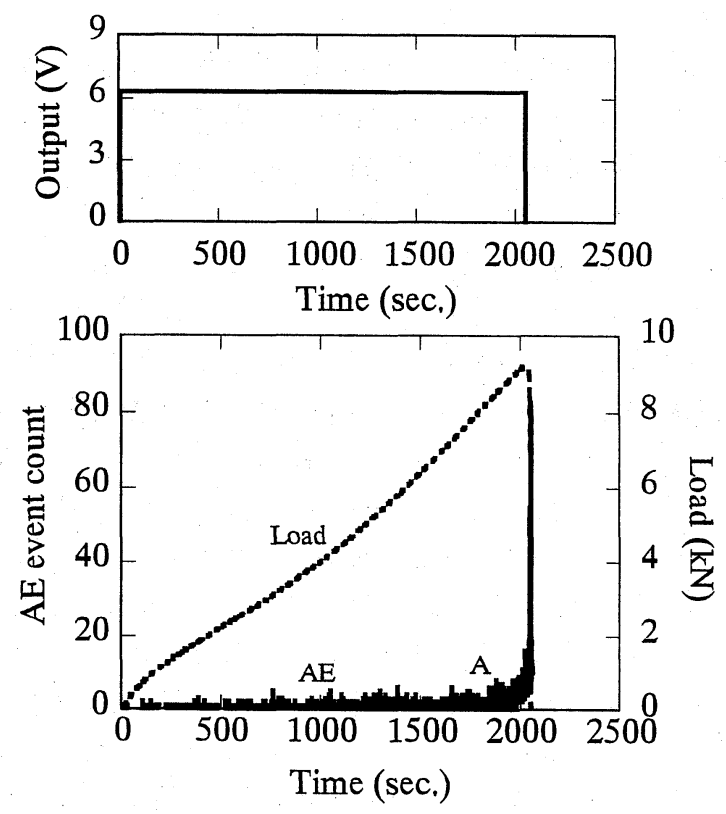

Fig. 9. Results of monitoring experiments for A type specimens (adhesives in cure). 
のの，接着部のはく離は検出できることがわかった．Fig. 12 に接着継手試験片の接着部のはく離破壊モードの模式 困を示す. 困に示すように，A タイプ試験片と同様，光 ファイバを埋め込んだ接着層および引き抜き GFRP の接 着部表面のマット層を引きはがして破壊している。した がって，この破壊モードより光ファイバによる接着部の はく離検出は，接着部の被着材に埋め込まれた光ファイ バが接着部のはく離破壊時に被覆材とともに引きはがさ れ，切断することにより可能であることがわかった。

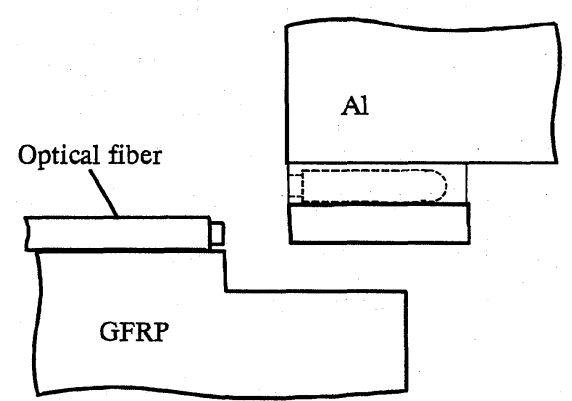

Fig. 10. Failure mode of A type specimens (adhesives in cure).
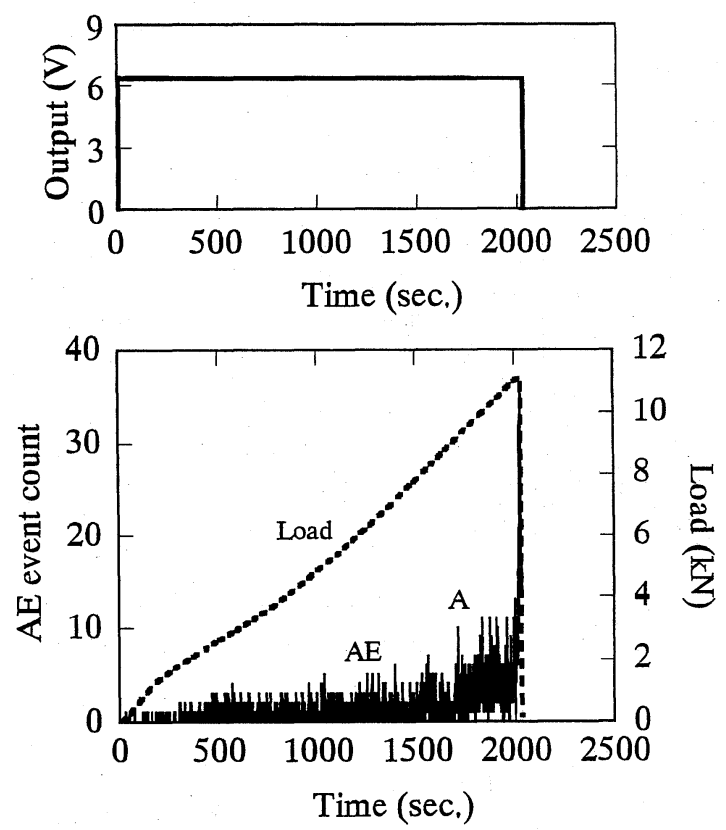

Fig. 11. Results of monitoring experiments for G type specimens (adhesives in cure).

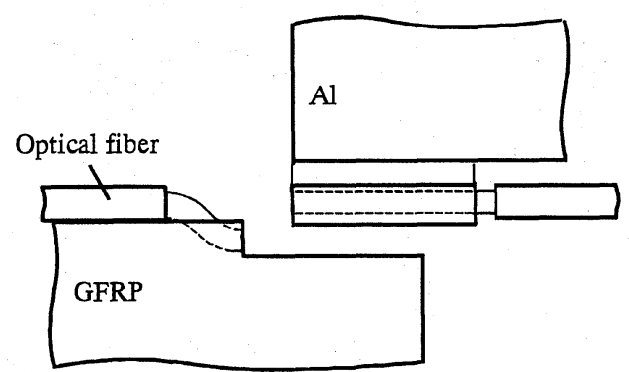

Fig. 12. Failure mode of $\mathrm{G}$ type specimens (adhesives in cure).
2・2・3 A タイプ試験片(接着剤が硬化不良状態) Fig. 13 に A イプ試験片の実験結果の一例を示す。困 において, 横軸は負荷時間, 縦軸には試験片に加えた荷 重と光ファイバ出力を示している. 図からわかるように 光ファイバ出力は, 接着継手試験片の破壊荷重の約 $70 \%$ の時点で 0 になっており，この時点で光ファイバが破断 していることがわかる. Fig. 14 にはく離破壊モードの摸 式図を示す．眓より，接着層に埋め込まれた光ファイバ はアルミニウム合金とともに, GFRP と接着層の接着界 面から引きはがされて破断していることがわかる．この はく離破壊モードより, 接着剤の硬化が不十分であるた め接着層のヤング率がかなり小さく，完全硬化の場合に 比べて負荷過程での接着層の変形が大きいため, 光ファ イバが接着端部で比較的早く破断したことが予想される. したがって, 完全接着の場合とは異なり，硬化不良状態 では比較的早期に接着継手のはく離を検出できることが わかった.

\section{2・2・4 G タイプ試験片(接着剤が硬化不良状態)}

Fig. 15 に $\mathrm{G}$ タイプ試験片のはく離検出実験結果の一例 を示す。この場合は, A タイプ試験片の場合とは異なり， 接着継手のはく離破壊の直前に光ファイバ出力が 0 にな っている. Fig. 16 にはく離破壊モードの摸式図を示す. 図より，GFRPの溝部分に接着剤とともに埋め込まれた 光ファイバが A タイプ試験片と同様，アルミニウム合金 とともに, GFRP と接着層の接着界面から引きはがされ て破断していることがわかる。これは，後に述べるよう に2 種類の試験片で接着層厚さがかなり異なっており， $\mathrm{G}$ タイプでは接着層が薄く, $\mathrm{A}$ タイプほど接着層が変形

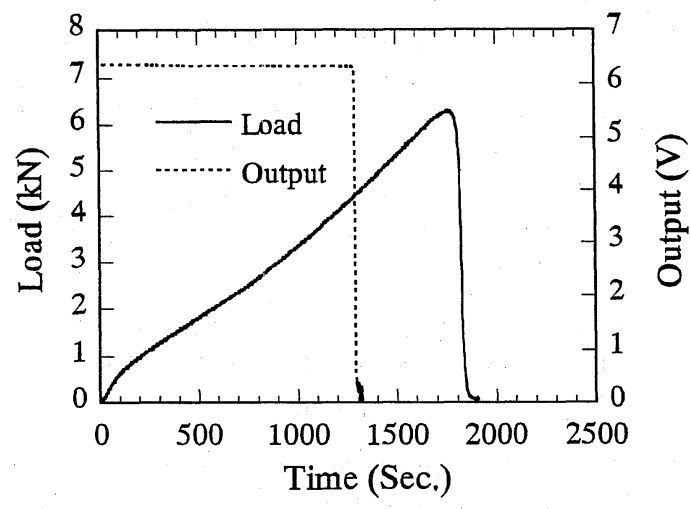

Fig. 13. Results of monitoring experiments for A type specimens (adhesives in undercure).

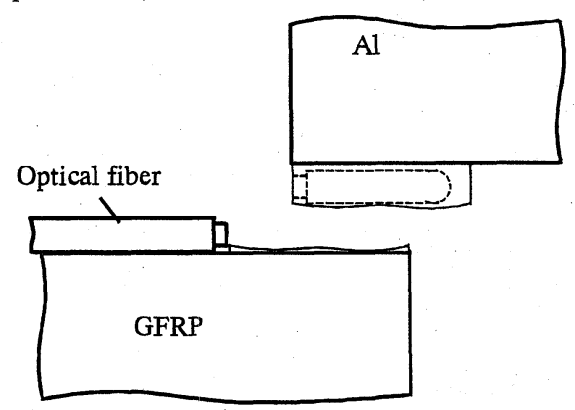

Fig. 14. Failure mode of A type specimens (adhesives in undercure). 
できないため, 光ファイバの破断が接着継手のはく離破 壊時に起こっているためであると考えられる，このはく 離検出結果は破壊モードは異なるものの, 完全接着試験 片の場合と同様であり, はく離検出が可能であることが わかった。

\section{3 光ファイバ埋め込みによる強度への影響}

\section{$3 \cdot 1$ 実験方法}

光ファイバ埋め込みによる接着継手強度への影響を調 べるために使用した A タイプ試験片の形状と寸法を Fig. 17 に示す。これははく離検出実験に使用した接着継手試 験片とほぼ同じであるが, 接着面積の影響を調べるため, 接着部の長さ $\mathrm{L} か ゙ 20,30,40 \mathrm{~mm}$ の 3 種類の試験片を準 備した。接着継手試験片の製作方法は, 幅約 $250 \mathrm{~mm}$ の 引き拔き GFRP およびアルミニウム板を接着剤で接着し て幅広の接着継手を作製し，幅 $40 \mathrm{~mm}$ に切り出しで試験 片とした. 光ファイバを埋め込んだ試験片と埋め込んで いない試験片の接着条件の違いによる継手強度への影響 を排除するため, $250 \mathrm{~mm}$ 幅の接着継手製作時に, 光フ アイバを接着継手試験片幅である $40 \mathrm{~mm}$ の間隔を空けて 埋め込み, 光ファイバを埋め込んだ試験片と埋め込んで いない試験片が交互に位置するようにした。なお， Gタ イプ試験片については, 試験片の幅を $20 \mathrm{~mm}$ とした。強 度測定はインストロン型試験機を使用し，引張速度 $3 \mathrm{~mm} / \mathrm{min}$ で行い, 破壊時の荷重を測定した。

\section{$3 \cdot 2$ 実験結果}

Fig. 18にA タイプ試験片の強度測定結果を示す。接 着継手強度は接着継手試験片の破壊荷重を接着面積で除

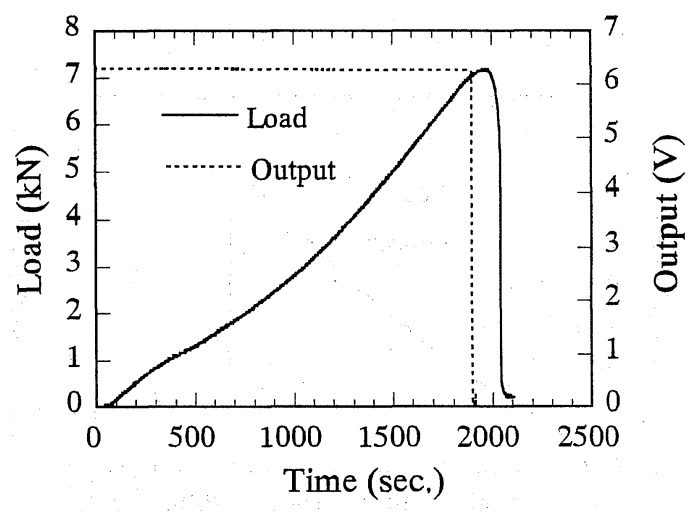

Fig. 15. Results of monitoring experiments for $\mathrm{G}$ type specimens (adhesives in undercure).

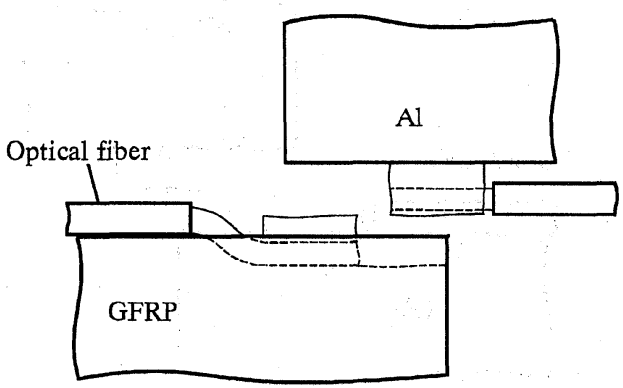

Fig. 16. Failure mode of $\mathrm{G}$ type specimens (adhesives in undercure).
した接着部の平均せん断強度で評価した。困において， 縦軸に継手強度, 横軸にラップ長さをとり, 光ファイバ を埋め込んだ試験片 (SAO) と埋め込んでいない試験片 (SA) 5 本の強度の平均值扎よび最大值から最小值までの 変動幅をそれぞれ示している。また，この研究より先に 行った同じ被着材を使用した $\mathrm{Al}$ 一引き抜き GFRP 接着 継手試験片 (SR) について行った強度測定結果 ${ }^{18)}$ を同時 に示している。この SR 試験片の強度值は, 本研究で使 用した試験片と全く同じ材料，接着方法により製作した 接着継手試験片 36 本について測定した結果である. SA 試験片には光ファイバが埋め込まれていないが，接着層 厚さは後に述べるように光ファイバを埋め込んだ SAO 試 験片と同じで, かなり厚くなっており，光ファイバを埋 め込んでいない試験片と全く同一であるとはいえない. したがって, SR 試験片の強度值を光ファイバを埋め込ん でいない試験片の本来の值として比較を行った．ただし， $\mathrm{SR}$ 試験片の幅は $20 \mathrm{~mm}$ である。罒からラップ長さが $30 \mathrm{~mm}$ では光ファイバを埋め込んだ $\mathrm{SAO}$ 試験片が $\mathrm{SA}$ 試 験片より少し高い值を示しているが, SR 試験片の強度と 比較したとき, いずれの強度もその変動幅に含まれてい ることから，光ファイバを埋め込むことによる強度へ影 響があるとはいえない。一方，ラップ長さ $20 \mathrm{~mm}$ と 40 $\mathrm{mm}$ では SAO, SA 試験片はほぼ同じ強度を示している.

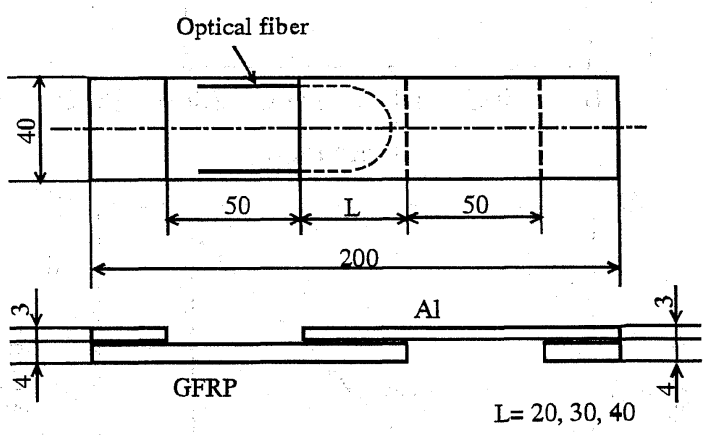

Fig. 17. A type specimen for comparing the strength of the joints with and without embedded optical fibers.

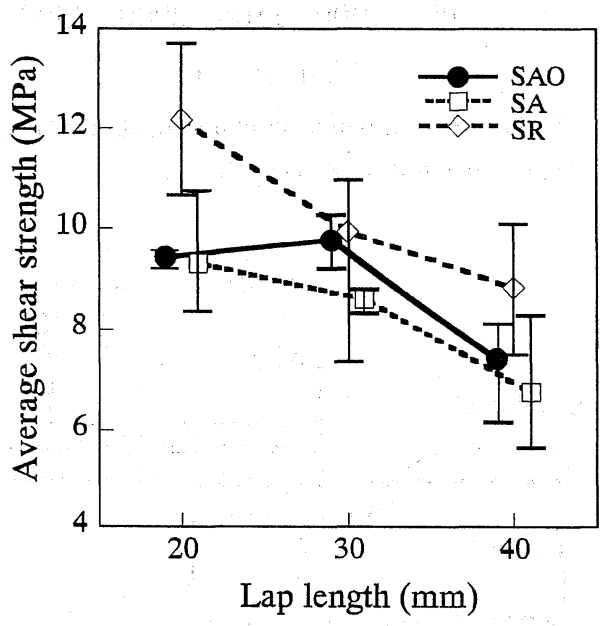

Fig. 18. Strength of A type specimens with and without embedded optical fibers. 
しかし, SR 試験片の強度と比較したとき, 強度の変動 幅を考慮しても，SAO，SA試験片いずれの強度も SR 試 験片の強度より低い值を示していることがわかる．これ らの結果から, A タイプ試験片では, 光ファイバを埋め 込むことにより継手強度を低下させる傾向があることが わかる

Fig. 19 に タイプ試験片について光ファイバを埋め 込んだ場合と埋め込まない場合の接着継手試験片の強度 測定結果を示す. 困においては, 光ファイバを埋め込ん だ試験片 (SGO) と埋め込んでいない試験片 (SG) 12 本の 強度の平均值および最大值から最小值までの変動幅を示 している.また, 比較のため Fig. 18 と同様, SR 試験片 の結果も示している。図より，SGO，SG 試験片いずれ も全てのラップ長さでほぼ同じ值を示している。一方, $\mathrm{SR}$ と比較した場合はラップ長さ $20 \mathrm{~mm}$ の試験片では, 強度の平均值では $\mathrm{SGO}, \mathrm{SG}$ 試験片のいずれも $\mathrm{SR}$ 試験 片より若干低い強度を示している。したがって, 強度へ の影響がみられるが, その変動幅を考慮するとA タイプ 試験片の $40 \mathrm{~mm}$ の強度結果に比べると影響は小さいよう にみえる、ラップ長さ $30 \mathrm{~mm}, 40 \mathrm{~mm}$ では平均值がほぼ

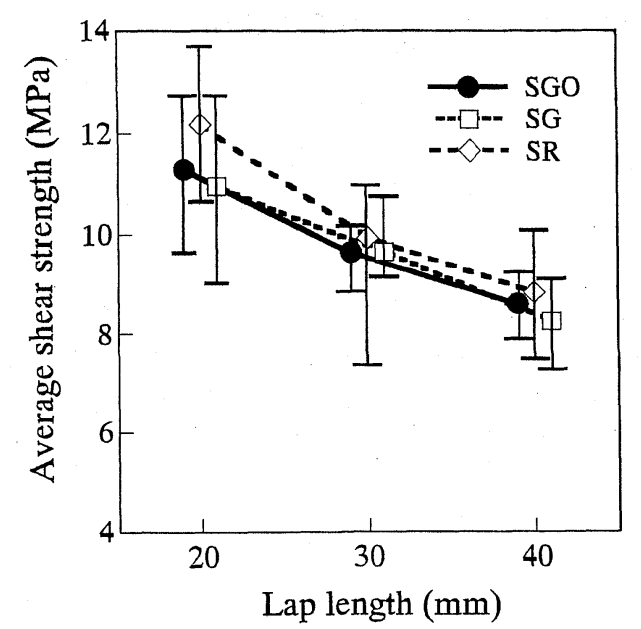

Fig. 19. Strength of $G$ type specimens with and without embedded optical fibers.

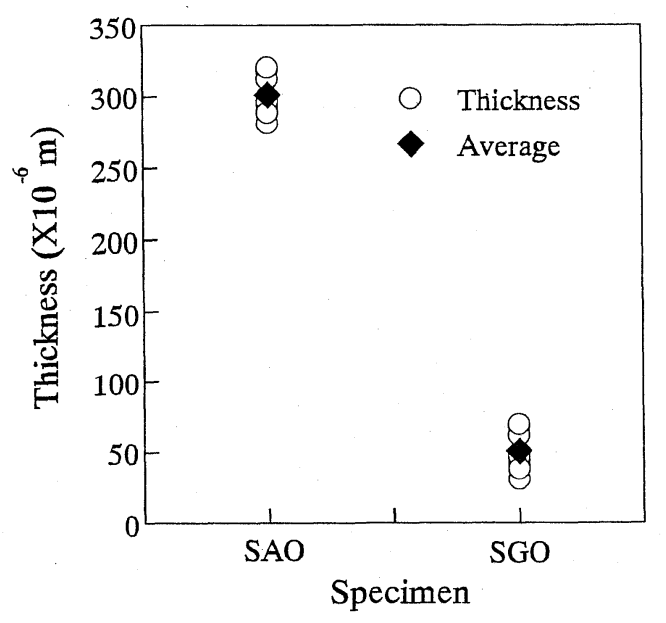

Fig. 20. Thickness of adhesive layers of $A$ and $G$ type specimens.
同じ值を示しており，また，SGO，SG 試験片は SR 試験 片の強度の変動の内に含まれることから，強度低下はみ られないことがわかる。これらの結果から，実際にはラ ップ長さを $20 \mathrm{~mm}$ 以下に設定するようなことはないため, 実用的には $\mathrm{G}$ タイプ試験片では光ファイバ埋め込みの有 無による強度への影響はみられないことがわかった。

次に $\mathrm{A}$ タイプの強度が低い值を示した原因を調べるた め, 2 種類の接着継手試験片について接着層厚さを測定

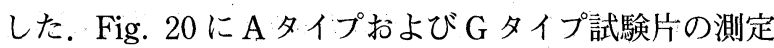
結果を示す. A タイプ試験片 (SAO) では接着層厚さが 約 300 ミクロンの值を示しているのに対して, G タイプ 試験片 (SGO) では, 約 50 ミクロンの值を示している. これらの結果より, A タイプ試験片が低い継手強度を示 したのは，接着部に光ファイバを埋め込んだため接着層 がかなり厚くなったことが原因であることがわかった

以上の結果より, 光ファイバを使った $\mathrm{Al}$ 一引き抜き GFRP 接着継手のはく離検出能力については $\mathrm{A}$ タイプと $\mathrm{G}$ タイプのいずれも，接着接合部のはく離破壊前の損傷 は検出できないものの, はく離については検出可能であ り，その検出能力についてはほぼ同等であることがわか った。しかし，光ファイバ埋め込みによる強度低下につ いては A タイプ試験片で埋め込みによる強度低下がみら れたのに対して，G タイプ試験片では実用的には埋め込 みの影響がみられなかったことから，接着部のはく離検 出方法としては $\mathrm{G}$ タイプの方が適していることがわかっ た.したがって， $\mathrm{Al}$ 一引き抜き GFRP 接着継手において は, 本研究で行った G タイプのように, 接着部の GFRP の表面に溝を作り光ファイバを埋め込んではく離を検出 する方法が，接着部のはく離のモニタリングに適してい ることがわかった

\section{4 結 言}

本研究では金属製の接合部品と引き抜き FRP の接着 接合部のへルスモニタリングを目的として $\mathrm{Al}$ 一引き抜き GFRP 接着継手を取り上げ，その接着接合部について接 合部に埋め込まれた光ファイバの破断を利用したはく離 検出法について検討した。本研究では接着層に光ファイ バを埋め込む方法（A タイプ）と，被着材の引き抜き GFRP の接着部に光ファイバを埋め込む方法（G タイプ） を採用した 2 種類のはく離検出法を取り上げ，そのはく 離検出能力について比較検討した. また, 接着剤が硬化 不良の状態におけるはく離検出能力および光ファイバを 埋め込んだことによる接着継手強度への影響についても 調べ，2種類のはく離検出方法について，そのへルスモ ニタリングへの適応性を検討した，その結果，以下のこ とがわかった.

(1) 2 種類の検出方法はいずれも，接着接合部のはく 離を検出できることがわかった。

(2) 2 種類の検出方法はいずれも, 接着凨が硬化不良 状態に扎いても, 接着部のはく離を検出できることがわ かった。

（3）光ファイバを埋め込んだことによる継手強度への 影響では, A タイプでは強度低下がみられるのに対して, 
G タイプでは実用上, 強度への影響がないことがわかった.

（4）光ファイバを接着部の引き抜き GFRP に埋め込む $\mathrm{G}$ タイプのはく離検出法は，はく離検出能力，および強 度への影響がないことから, $\mathrm{Al}$ 一引き抜き GFRP 接着接 合部におけるへルスモニタリングに適していることがわ かった。

最後に, 本研究を行うに際して協力して頂いた, 本学 平成 9 年度卒業の加藤嘉記君に感謝申し上げる。また, 実験を行うに際し，多大なる協力を頂いた石川島播磨重 工業(株)北出真太郎氏に御礼申し上げる.

\section{参 考 文 献}

1) S. Ramakrishna, H. Hamada, T. Nishiwaki and Z. Maekawa, Proc. Int. SAMPE Symposium and Exhibition, 40, 540 (1995).

2) R. Prabhakaran, Z. Razzaq and S. Devara, Composites, B27, 351 (1996).

3) A. Pickett, L. Hollaway and L. N. Phillips, Composites, p.257 (1982).

4) A. Mahoon, Composites, 18, 229 (1988).

5) D. A. Jackson, J. Phys. E : Sci. Instrum., 18, 981 (1985).

$6)$ S. R. Waite, R. P. Tatam and A. Jackson, Composites, 19, 435 (1988).
7) K. Kiu and R. M. Measures, J. Intell. Mater. Syst. and Struct., 3, 432 (1992).

8）福田武人, 逢坂勝彦, 北出真太郎, 材料, 42, 269（1993）.

9) V. Bhatia, K. A. Murphy, R. O. Claus, T. A. Tran and J. A. Greene, Smart Mater, Struct. 4, 245 (1995).

10) M. A. El-sherif and J. Radhakrishnan, J. Reinf. Plast. Compos., 16, 144 (1997)

11) R. M. Crane and A. B. Macander, Naval Eng. J., p.52 (1984).

12) N. D. W. Glossop, S.Dubois, W. Tsaw, M. Leblanc, J. Lymer, R. M. Measures and R. C. Tennyson, Composites, 21, 71 (1990).

13) 北出真太郎, 福田武人, 逢坂勝彦, 強化プラスチックス, 40, 54 (1994).

14) S. R. Waite, Composites, 21, 148 (1990).

15) 北出真太郎, 福田武人, 逢坂勝彦, 材料, 44,1196 (1995).

16) B. Hoffer, Composites, 18, 309 (1987).

17) 高橋 淳, 野村正人, 武田真一, 津田 浩, 剣持 潔, 福田 博, 日本材料学会第 27 回 FRP シンポジウム講演論 文集, p.255 (1998).

18) 逢坂勝彦, 福田武人, 坂本勝彦, 溶接学会溶接構造シンポ ジウム '97 講演論文集, p.347 (1997). 